\title{
The diet composition of breeding Ospreys (Pandion haliaetus) in Latvia
}

\author{
Aigars Kalvans ${ }^{1 *}$, Janis Bajinskis ${ }^{2}$ \\ ${ }^{1}$ Joint Stock Company “Latvian State Forests", Vainodes 1, Riga LV-1004, Latvia \\ ${ }^{2}$ Institute of Food Safety, Animal Health and Environment “BIOR”, Fish Resources Research Department, Daugavgrivas 8, Riga \\ LV-1084, Latvia \\ *Corresponding author, E-mail: a.kalvans@lvm.lv
}

\begin{abstract}
The diet composition of breeding Ospreys (Pandion haliaetus) was studied in several location in Latvia from 2009 to 2015 by determining food remains, intact or partly eaten fish in the nests, and photo and video materials from surveillance cameras that were set up at 14 nests. During the study period, information about 1501 Osprey prey specimens was collected from 119 nests and they were all fish. In total, 15 fish species were identified in Osprey diet, of which the most numerous was common carp (Cyprinus carpio), representing 47.2\% of the diet, followed by tench (Tinca tinca) 14.3\% and Prussian carp (Carassius gibelio) 11.3\%, which was not found in studies conducted in other countries. The mean size of all mesured fish was $27.8 \mathrm{~cm}$ and corresponding weight was 368 g. Predatory fish (pike Esox lucius, perch Perca fluviatilis) represented only $4.7 \%$ of the whole diet. Osprey diet composition in Latvia showed that the population highly relies on fishponds.
\end{abstract}

Key words: diet composition, Latvia, Osprey, Pandion haliaetus.

\section{Introduction}

Ospreys (Pandion haliaetus) are piscivorous birds that feed on fish. Fish composition in the Osprey diet depends on season and geographical location (Poole 1989). There is information about Osprey dietary composition in European countries (Häkkinen 1978; Carss 1994; Müller 2005; Babuskin, Kuznicov 2012; Ivanovski 2012), but in Latvia such studies have not been conducted.

Currently in Latvia there are 210 to 230 breeding pairs of Osprey. The population has increased by more than four times in the past 30 years. Breeding success in Latvia is high with 2.33 nestlings on average per successful nest (Kalvans 2013). It is possible that population growth and high breeding success is associated with food availability. This study was conducted to describe the diet of Osprey in Latvia in relation with breeding success.

\section{Materials and methods}

\section{Study design}

The study was carried out in 119 sites in Latvia from 2009 to 2015. We used the following methods to determine diet composition of Osprey (Pandion haliaetus) in this study: collection of biological materials from nests (scales, bones etc.), collection of intact or partly eaten fish in the nests, and use of photo and video surveillance cameras at nests (Table 1).

\section{Biological materials from the nests}

All visually recognized biological materials of fish were collected from Osprey nests: scales, bones, skin fragments. Material was collected from 2009 to 2014 on average from 71 nests per year (most in 2014, 95; least in 2009, 49). Collection of material from nests was made once in each season, when Osprey chicks were ringed.

\section{Photo and video surveillance cameras}

From 2011 to 2015, video surveillance cameras Mobotix M24M-Sec-D32 were placed at three nests. At one nest site, video surveillance cameras were placed two years in a row. The cameras worked with small interruptions throughout the breeding season (April to August). From one season, information was obtained from up to 400 fish that Osprey brought to the nest. For approximately $70 \%$ of the fish individuals it was possible to determine the species. Fish species was determined by fish body shape, tail, fin and skin color, as well as pattern. In addition photo cameras Moultrie M100 that respond to movement were placed at 11 nests. Usually the cameras were operational approximately from one to two months, mostly at the beginning of the breeding season (April, May) or at the end of it (July). Cameras also recorded the date and time.

\section{Fish from the nests}

When annually checking the nests, intact or partly eaten fish were found in the nests. From 2009 to 2014 in total 
Table 1. Methods used in the present study with total number of nests investigated

\begin{tabular}{|lll} 
No. & Method & $\begin{array}{l}\text { Number of } \\
\text { nests }\end{array}$ \\
\hline 1 & Biological materials from nests & 113 \\
\hline 2 & $\begin{array}{l}\text { Photo and video surveillance cameras at } \\
\text { nests }\end{array}$ & 14 \\
3 & Fish from the nests & 48 \\
\hline
\end{tabular}

60 fish were found (on average 10 fish per year, biggest number in 2013, 22 fish). To determine length and weight of Ospreys prey specimens, each fish was measured. Fish weight was determined by the length-weight relationship equation:

$$
W=a \times L^{b},
$$

were $W$ is weight of fish (g), $L$ is length of fish ( $\mathrm{mm})$, and $a$ and $b$ are coefficients (Anderson, Neumann 1996).

In total information about Osprey diet composition was obtained from 119 nests.

\section{Results}

In the seven-year period, information was obtained on 1501 Osprey prey specimens. Most of the data was obtained from photo and video surveillance cameras (68\% of the identified prey specimens).

In analysed biological material from Osprey nests dominant structures were scales, skin fragments and opercular bones, less found remains of fins, vertebrae, pharyngeal teeth and other skull bones.

In total 15 fish species identified belonging to six families (Anguillidae, Coregonidae, Cyprinidae, Esocidae, Percidae, Salmonidae) (Table 2).

With photo and video surveillance cameras we identified the biggest number of fish species, but the most accurate results with the least amount of unidentifiable fish species was obtained by analyzing intact or partly eaten fish found in the nests. In total 60 fish were found in the nests during the study period, belonging to 11 species, on average 10 fish per year (most in 2013, 22 fish). The mean length of fish (Fig. 1) was $27.8 \mathrm{~cm}$ [smallest $16 \mathrm{~cm}$ (tench); maximum $48 \mathrm{~cm}$ (rainbow trout)], and the average weight was $368 \mathrm{~g}$ (minimum $60 \mathrm{~g}$, maximum $1080 \mathrm{~g}$ ).

The Osprey diet in Latvia consisted mostly of Cyprinidae fish. Nearly half of the diet was composed of common carp (47.2\%), tench (14.3\%), and Prussian carp (11.3\%). Bream (8.7\%) and crucian carp (5.9\%). Although generally predatory fish species in Osprey diet took just a small part, in certain Osprey nests rainbow trout had a major role in the diet: $41 \%$ of the total amount of fish brought to the nest.

Seasonal variation of prey species were not observed. Also, differences between study years in species preferences in Osprey diet were not observed.

The photo and video surveillance cameras showed that an Osprey pair during the breeding season brings daily three fish to the nest. The biggest amount of fish brought to the nest during a day was 10 fish, and such a quantity of fish was recorded twice.

\section{Discussion}

Some studies have shown presence of birds and small mammals (mainly rodents), as well as reptiles and amphibians in the Osprey diet (Karjakin 1998; Ivanovski 2012). Although in our study the analysed quantity of material is much larger than in similar studies made in Europe (Table 3), we found only fish in the Osprey diet. It is likely that occurrence of non-fish animals in the Osprey diet is an exception and related to famine conditions when fish are not available. Such circumstances are possible at the beginning of the breeding season (early spring), and in

Table 2. Percentage of different fish species in Osprey diet

\begin{tabular}{|c|c|c|c|c|c|}
\hline \multirow[t]{2}{*}{ No. } & \multirow[t]{2}{*}{ Species } & \multicolumn{4}{|c|}{ Method (numbers according to Table 1) } \\
\hline & & $1(n=426)$ & $2(n=1015)$ & $3(n=60)$ & 1 to $3(n=1501)$ \\
\hline 1 & Perch Perca fluviatilis & 0.2 & 1.3 & 1.7 & 1.0 \\
\hline 2 & Common carp Cyprinus carpio & 46.9 & 49.2 & 15.0 & 47.2 \\
\hline 3 & Crucian carp Carassius carassius & 14.1 & 2.8 & 1.7 & 5.9 \\
\hline 4 & Pike Esox lucius & 4.5 & 3.5 & 1.7 & 3.7 \\
\hline 5 & Tench Tinca tinca & 5.9 & 17.8 & 15.0 & 14.3 \\
\hline 6 & Bream Abramis brama & 4.2 & 9.8 & 23.3 & 8.7 \\
\hline 7 & Silver bream Blicca bjoerkna & 0.2 & 1.0 & 3.3 & 0.9 \\
\hline 8 & Roach Rutilus rutilus & 1.9 & 0.3 & 8.3 & 2.3 \\
\hline 9 & Rudd Cardinius erythrophthalmus & 0.0 & 0.3 & 0.0 & 0.2 \\
\hline 10 & Chub Squalius cephalus & 0.0 & 0.5 & 1.7 & 0.4 \\
\hline 11 & Prussian carp Carassius gibelio & 21.6 & 6.6 & 18.3 & 11.3 \\
\hline 12 & Rainbow trout Oncorhynchus mykiss & 0.2 & 5.0 & 10.0 & 3.9 \\
\hline 13 & $\begin{array}{l}\text { Other (ide Leuciscus idus, whitefish } \\
\text { Coregonus lavaretus, eel Anguilla anguilla) }\end{array}$ & 0.2 & 0.2 & 0.0 & 0.2 \\
\hline
\end{tabular}




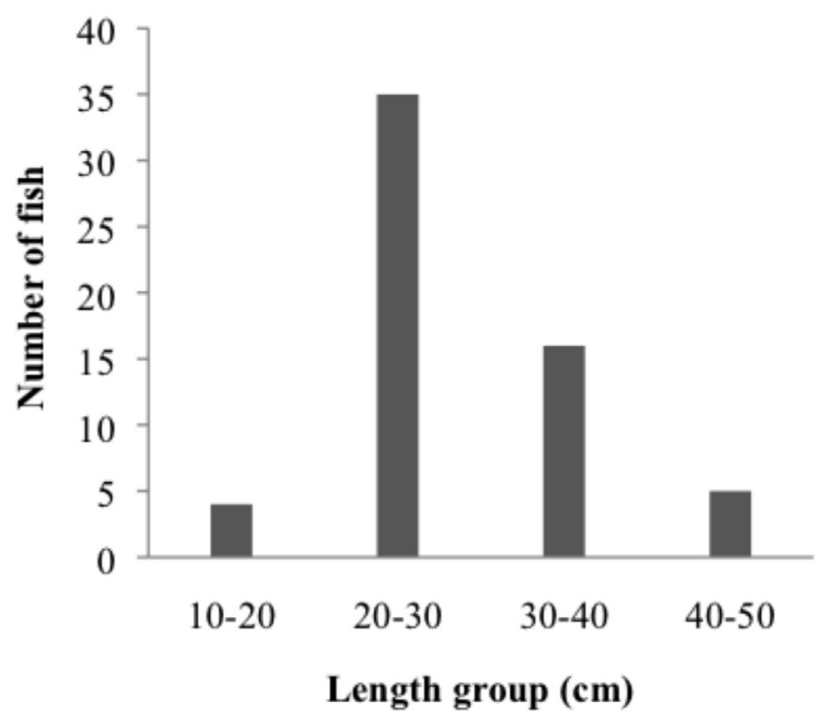

Fig. 1. Quantity of fish from different length size groups in the Osprey diet.

regions where there are only natural water reservoirs with low amounts of fish resources.

By using various Osprey diet composition assessment methods, we obtained slightly different distribution of fish species in diet, as it was possible to collect only those calcified structures (bones, scales) and skin residues which were larger in size and which were not easily burried by nest materials or decomposed quickly. Presumably, it is why the biological material there contained low amounts of remains of fish species that have small calcified structures. However, the method of biological material analysis reflects the dominant fish species in the Osprey diet and on the average it corresponds to results obtained by other diet composition assessment methods.

Most of the identified prey specimens in diet of Latvian Osprey are typical of fish ponds. A similar situation was also observed in a study conducted in Northeast Germany (Müller et al. 2005). In our study, the average distance from Osprey breeding nests to fish ponds or lakes was from 3 to $6 \mathrm{~km}$, which is within the typical Osprey foraging distance range (Vana-Miller 1987; Poole 1989). In other studies it was observed that Osprey foraging flights can cover be over much larger distances (13 to $14 \mathrm{~km}$ ) (Flemming, Smith 1990; Hagan, Walters 1990). Common carp, crucian carp, Prussian carp, tench and bream are popular aquaculture species. These species have also been propagated artificially in natural water bodies. In 2014, 153 aquaculture companies were registered in Latvia and about $90 \%$ of them use open fish ponds, rather than pools or recirculation systems (Mitāns 2014). In recent years the number of fish ponds has been growing and fish in the ponds are available in relatively dense concentrations, creating favourable conditions for a stable Osprey population due to easily accessible food for Osprey throughout the breeding season. Ospreys often prey on fish that are in high density and swim closer to the water surface (Francour, Thibault 1996). Although the diet of Ospreys in Latvia is dominated by fish that are characterized by benthic feeding and lifestyle, the high density of them in fish ponds alter their behaviour and make them more easily accessible to Osprey than in natural waters. In natural waters Osprey tend to attack fish (mainly roach, bream) that are infested with Ligula intestinalis. Plerocercoid larva of this cestode parasitize in the fish abdominal cavity, which has severe effect on its hosts behaviour and vision, causing them to remain near the water surface where they are vulnerable prey to birds (Brown et al. 2002; Babuskin, Kuznecov 2012). Swenson (1979) found that fish feeding on benthos are easier catch for Osprey rather than predatory fish species, because they are slower and more focused on substrate of the water body, while predatory fish pay attention to the whole surrounding area. Osprey is a visual predator that relies on sight for hunting. In fish ponds, where the fish are provided with favourable growing conditions, they quickly reach suitable prey size, and they are less cautious.

Average size of Osprey prey specimens $(27.8 \mathrm{~cm})$ in Latvia is quite similar to that found in other countries (Häkkinen 1978; Marquiss et all. 2007; Babuskin, Kuznecov 2012), but it is higher than in Western Russia, where Osprey feed mainly on fish with a mean length of $20 \mathrm{~cm}$ and mean weight of $340 \mathrm{~g}$ (Galusin 1958). Dominance of larger fish in Osprey diet composition was found in studies conducted in Scotland, where Osprey more often feed on salmonids (Table 3). There the average length of Osprey prey specimens was $34 \mathrm{~cm}$ and corresponding weight was $480 \mathrm{~g}$ (Carss, Brockie 1994).

Dominance of cyprinids in Osprey diet during the breeding season was observed in our study and in studies in Belarus, Finland, Germany, Russia and Sweden (Galusin 1958; Schnurre, Thumann 1961; Häkkinen 1978; Eriksson 1986; Hake 1996; Karjakin 1998; Müller et al.2005; Babuskin, Kuznicov 2012; Ivanovski 2012). All of these studies show that bream has a significant role in Osprey diet, although in Latvia other species have a greater contribution in the diet of Osprey. Probably, it is not easily available in large quantities compared to common carp or Prussian carp. Also, bream usually stays in deeper waters.

Prussian carp, which constitutes a large part (11.4\%) of the diet of Osprey in Latvia, has not been observed in other similar studies carried out in Europe. This invasive fish species was introduced into Latvia in 1948 for cultivation in fish ponds and now it is commonly stocked together with common carp. Prussian carp have spread widely in the inland waters of Latvia and in the Gulf of Riga. In Ireland, Scotland and northern Baltic basin this species is absent, and is not common in other European countries (Gorgan, Ciorpac 2013). The role of ide Leuciscus idus, whitefish Coregonus lavaretus and eel Anguilla anguilla in diet of Osprey is negligible in Latvia.

In conclusion, the results of the present study suggest 


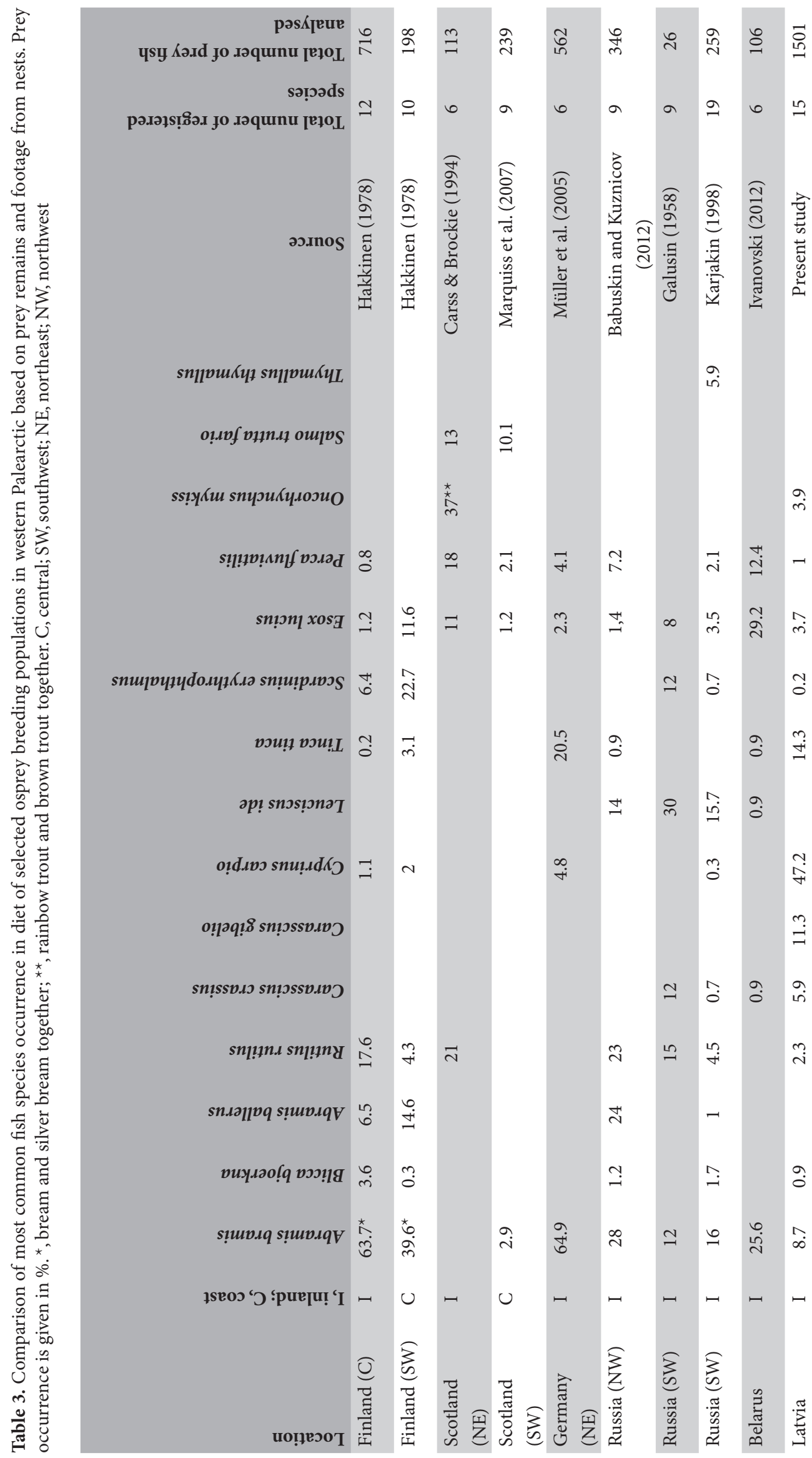


that the growth of the Osprey population in Latvia and high breeding success is closely linked to the surge of fish pond aquaculture and fish stocking in recent years (Mitāns 2014). These habitats provide a stable and easily available food resources throughout the breeding season.

\section{Acknowledgements}

Most of the video surveillance cameras for this study were purchased, placed and maintained with financial support from various Latvian Nature Fund projects. The authors express sincere thanks to all who participated in the nest checking and collection of materials. Also thanks to Janis Pèrle for the help of identification of certain fish species, placement and maintenance of photo and video surveillance cameras and data processing.

\section{References}

Anderson R.O., Neumann R.M. 1996. Length, weight, and associated structural indices. In: Murphy B.R., Willis D.W. (eds) Fisheries Techniques. American Fisheries Society, Bethesda, 447-482.

Babuskin M.V., Kuznicov A.V. 2012. Diet of the Osprey in the Darwin Nature Reserve (North-Western Russia). Proceedings of the VI International Conference on Raptors and Owls of Northern Eurasia, 330-334. /in Russian/

Brown S.P., Loot G., Teriokhin A., Brunel A., Brunel C., Guégan J.F. 2002. Host manipulation by Ligula intestinalis: a cause or consequence of parasite aggregation? Int. J. Parasitol. 32: 817-824.

Carss D.N., Brockie K. 1994. Prey remains at Osprey nests in Tayside and Grampian 1987-1993. Scott. Birds 17: 132-145.

Eriksson M.O.G. 1986. Fish delivery, production of young and nest density of Osprey (Pandion haliaetus) in southwest Sweden. Can. J. Zool. 64: 1961-1965.

Flemming S.P., Smith P.C. 1990. Environmental influences on Osprey foraging in Northeastern Nova Scotia. J. Reptor Res. 24: 64-67.

Francour P., Thibault J.C. 1996. The diet of breeding Osprey Pandion haliaetus on Corsica: exploitation of a coastal marine environment. Bird Study 43: 129-133.
Galusin V.M. 1958. On the ecology of the Osprey Pandion haliaetus in the Oksky Reserve. Trudy Oksky Reserve 2: 158161. /in Russian/

Gorgan L.D., Ciorpac M. 2013. Identification of Carassius gibelio migration patterns in Europe. AACL Int. J. Bioflux Soc. 6: 9296.

Hagan J.M. III, Walters J.R. 1990. Foraging behavior, reproductive success, and colonial nesting in ospreys. Auk 107: 506-521.

Hake M. 1996. Home range and feeding preference of the Osprey during late breeding season in south central Sweden. In: Pandolfi M. (ed) European and Mediterranean Osprey Symposium. $2^{\text {nd }}$ International Conference on Raptors, $2^{\text {nd }}-5^{\text {th }}$ October 1996. Urbino, Italy.

Häkkinen I. 1978. Diet of the Osprey Pandion haliaetus in Finland. Ornis Scand. 9: 111-116.

Ivanovski V.V. 2012. Predator Birds of Belarusian Lake District. Vitjepsk. /in Russian/

Kalvans A. 2013. Study and protection of Ospreys in Latvia. Birds of prey and owls in zoos and nurseries 22: 29-39. /in Russian/

Karjakin I.V. 1998. Avian predators of the Ural region. Falconiformes (Falconiformes), Owls (Strigiformes). Center for Field Studies Conservation Union Urals Animals. Perm, 2-16. /in Russian/

Marquiss M., Robinson L., Tindal E. 2007. Marine foraging by Ospreys in southwest Scotland: implications for the species' distribution in Western Europe. British Birds 100: 456-465.

Mitāns A. 2014. Review of aquaculture article topics in Latvian Fisheries Yearbooks 1997-2013. Latvijas zivsaimniecības gadagrāmata. Rīga, 2014. 102. /in Latvian/

Müller T., Langgemach T., Sulzberg K., Köhler D. 2005. Artenschutzprogramm Adler. Ministerium für Ländliche Entwicklung, Umwelt und Verbraucherschutz des Landes Brandenburg (MLUV)). Potsdam, Germany, 92.

Poole A. 1989. Ospreys: A Natural and Unnatural History. Cambridge University Press, Cambridge.

Schnurre O., Thumann M.A. 1961. Zur Ehahrung des Fischadlers (Pandion haliaetus)). Beitrage zur Vokelkunde 7: 284-290.

Swenson J.E. 1979. The relationship between prey species ecology and dive success in Ospreys. Auk 96: 408-412.

Vana-Miller S. 1987. Habitat suitability index models. Biological Reports 82: 46. 